\title{
Habitar el relámpago ${ }^{1}$
}

Por Norman Paba Zarante ${ }^{2}$

\section{Proemio}

Para todas las que no participaron en una revolución, para las que arrojaron a sus niños desde lo alto de la montaña y luego sonrieron satisfechas mientras la brisa aullaba, para las que perdieron la cabeza por amor una y otra vez y odiaron tanto ese corazón entregado que desearon ser hombres y follar su propio cuerpo con la rabia de las cosas oxidadas, para las que apagaron cigarrillos en sus vientres con natural felicidad luego de visitar al ginecólogo, para las que murieron de sobredosis en callejones, en bares y en cuartuchos infectos, para las que nunca lucharon ni les interesó hacerlo, para las rubias destruidas estáticas en su propia contemplación de animal de centella, para las que se emborrachaban hasta perder el camino a casa y a sus vidas, para las que la ternura, ese extravío, destruyó sistemáticamente. Este es su canto, su llaga perfecta, de azafrán, de jazmín, de las diez mil hogueras donde arde toda la belleza.

\footnotetext{
${ }^{1}$ Presentamos a nuestros lectores los poemas de Habitar el relámpago (2017), plaquette del poeta colombiano Norman Paba Zarante, quien ha sido ganador de la convocatoria de Idartes Residencias Artísticas en Bloque Ciudad de Bogotá (2017), con el proyecto "Habitar el Relámpago" (Fundación Poética de Espacios No Convencionales).

${ }^{2}$ Norman Paba Zarante, poeta colombiano nacido en Cartagena en 1985. Profesional en Lingüística y Literatura de la Universidad de Cartagena y Magíster en Escrituras Creativas de la Universidad Nacional de Colombia (Bogotá). Ha participado en la antología de poesía colombo-peruana En tierras del cóndor (Taller de Edición Rocca) y en Luna nueva. Antología Múltiple III (Diecinueve miradas a la poesía colombiana). Algunos de sus poemas han sido traducidos al francés, inglés e italiano. Tiene inédito el libro de poemas La noche incinerada.
} 


\section{Dormir}

Dormir en sofás endurecidos por el frío.

Dormir en callejones, en puentes, en plazas, mientras las ratas bailan un vals con tu hambre.

Dormir

con toxicómanas violentas aullando de emoción

ante la posibilidad de una nueva dosis.

Dormir, perseguido por las jaurías del amor,

en un Cadillac dios de óxido y ruido.

Dormir con las luces encendidas por miedo al fin del mundo.

Dormir en habitaciones destruidas por la fiesta,

en trincheras, en cráteres salvajes.

Dormir borracho y despertar en medio de un hospital

ciego de golpes.

Dormir enfermo en el altillo del apartamento 202

5 gatos furtivos y la amistad más generosa

desplegándose.

Dormir esposado en estaciones de policía, dormir en bibliotecas, en taxis que regresan a ningún lugar.

Dormir en moteles del desierto

donde la certeza de la inminente y estruendosa derrota

seduce a mi desesperación.

Dormir

en ese único avión

que cae en medio del infierno.

Dormir con Angélica, su cuerpo perfecto de 1 metro 79

cuchillo de luz que parte el aire, parte la madrugada

irrumpiendo como milagro,

breve tigre de Kafka, fogata alucinada.

Dormir

arrullado por el resplandor de las bengalas,

en altamar,

escuchando la conversación subterránea de todas las cosas vivas. 


\section{Teoría del vuelo}

All things are one.

All things are joined

even beyond the edge of sight

Mark Strand

A diez mil pies de altura todas las cosas están hermanadas. Partículas de polvo igualan el tamaño de planetas

y en las calles

los árboles arden y los niños arden

como bestias heridas

que segregan una única visión

de montaña enloquecida bajo un filo múltiple.

Y yo, perpetuo proyectil cayendo sobre los aeropuertos,

exhalo pasión por las piras funerarias

por el olor de la hierba mordida por la humedad.

A diez mil pies de altura

todas las cosas vuelven a ser una.

Luz aplastada hasta la ceniza.

Elemental equilibrio de fuerzas desatadas.

A diez mil pies de altura me desintegro

el pago por mis poemas no llega

y los días de oro son viejas amantes muertas

bailando la dura canción de una nostalgia salvaje.

Arruinado nuevamente

recurro a la poesía

ingrata puta de mil caras

prefiere una cena de piedra bajo la luz de las farolas

prefiere habitaciones calientes y el suave relámpago

de narcóticos aplicados vía intravenosa,

no la reprocho.

A diez mil pies de altura

lanzo un beso al libro de Miłosz olvidado sobre mi escritorio ¿Qué clase de poesía es aquella que no salva naciones o pueblos? 


\section{Visión de San Victorino}

A la manera de Hieronymus Bosch

Niños visionarios arrojados a la hoguera

y viejos toxicómanos destruidos

ofreciendo sus llagas a tambaleantes ángeles del vértigo

detectives del fulgor

que ofrecieron su mente en sacrificio

para despertar tan solo a los tres días

con oro en sus libretas

y la certeza de un nuevo astro

alumbrando el material cambiante de la furia.

Suicidas de cristal paranoico estallando

la calma sorda de las avenidas.

Siniestros productores pornográficos

ejercitando carne podrida

desde el doceavo piso de una pesadilla

con gabanes de cuero sintético y paredes cubiertas en plástico.

Pederastas constelados de horror

cuyos dientes

como los dientes de una cantante muerta

resplandecen en teatros y azoteas.

Putas vestidas de un rojo violento

inestables traficantes de Mini Uzis

enseñando que la belleza sucede

a una cadencia de 950 disparos por minuto. 


\section{Suma}

Ser un violento ángel de Caravaggio

visión narcótica de la Gracia.

Ser la pantalla borrosa de un cine pornográfico.

Ser el amante baleado a media noche

gacela herida en la tela del sueño.

Ser la calma anterior,

el jardín cercado por las llamas,

una ciudad aplastada por la artillería de dioses enemigos.

Ser Chet Baker, un diamante tallado y robado en Oklahoma, delirio de trompetas volando entre lujosos hoteles

y la muerte.

Ser un monje salvaje en perpetuo éxtasis

adusta serenidad sobre el lomo curvado del relámpago.

Ser la fuga, la lluvia, un fuego de hojas secas.

Ser

el más hermoso cuchillo

clavado en el corazón del mundo. 


\section{Calma}

\section{Para Verónica Ardila}

Lanzarse a las vías de un tren que no existe en una ciudad bombardeada y olvidada en el sueño.

Vivir en los libros, en la pantalla de un cine, en minúsculas habitaciones donde solo palpita tu respiración de puro fragor, pulso de ruinas doradas bajo el ojo salvaje del amanecer. Bailar con cuchillos mientras las ambulancias rugen y el mundo ruge y la tranquila apariencia de las grietas es la única música posible.

Derrochar todo dinero en cerveza y cocaína, y una angustia tan bella como para huir travestido en aerolitos de furiosa carne. Jugar con las ilusiones perdidas hace tanto tiempo, una tarde de agosto, cuando atravesábamos la avenida Santander en un viejo Mazda y tú mirabas a través del parabrisas a las gaviotas sobrevolando como diosas del destierro la orilla del mar, y yo pensaba que podíamos estar allí en la carretera, para siempre, amándonos. 